\title{
PRIMEIRAS NOTAS PARA UM CATÁLOGO: LEVANTAMENTO DOS PROCESSOS JUDICIAIS DO PODER JUDICIÁRIO DO ESTADO DE SANTA CATARINA (1791-1988)
}

\section{FIRST NOTES FOR A CATALOG: SURVEY OF THE JUDICIAL PROCESSES OF THE JUDICIAL POWER OF THE STATE OF SANTA CATARINA (1791-1988)}

\begin{abstract}
Adelson André Brüggemann*
Resumo: Neste artigo são relatadas as atividades de levantamento, catalogação e diagnóstico do acervo documental composto pelos processos judiciais do Poder Judiciário do Estado de Santa Catarina, desde fins do século XVIII até o ano de 1988. Além disso, são apresentados os primeiros dados necessários para a construção de um catálogo de documentos judiciais em Santa Catarina. Durante a fase de levantamento, foram mobilizadas dezenas de instituições culturais e/ou de ensino em todo o Estado, além das comarcas que compõem a Justiça Estadual catarinense. Com isso, foi possível mapear a localização de milhares de processos judiciais em todo o território do Estado e suas condições de conservação, bem como traçar planos para futuras atividades, com o intuito de alcançar melhores resultados quanto ao fornecimento de acesso a esse importantíssimo acervo documental sob custódia não somente do Tribunal de Justiça de Santa Catarina, como também de outras instituições.
\end{abstract}

Palavras-Chave: Poder Judiciário. Patrimônio Arquivístico. Documentos Judiciais.

Abstract: In this article, the activities of surveying, cataloging and diagnosing the documentary collection made up of the judicial processes of the Judiciary Power of the State of Santa Catarina are reported, from the end of the 18th century to the year 1988. In addition, the first data necessary for the construction of a catalog of court documents in Santa Catarina are presented. During the survey phase, dozens of cultural and / or educational institutions were mobilized throughout the State, in addition to the counties that make up the State Justice of Santa Catarina. As a result, it was possible to map the location of thousands of lawsuits across the state and their conservation conditions, as well as outline plans for future activities, with the aim of achieving better results in terms of providing access to this very important documentary collection in custody not only of the Santa Catarina Court of Justice, but also of other institutions.

Keywords: Judiciary Power. Archival Heritage. Court Documents.

Recebido: 24/07/2020 Aceito: 02/09/2020

\footnotetext{
* Mestrado em História pela Universidade Federal de Santa Catarina (UFSC). Graduado em História pela Universidade do Estado de Santa Catarina (UDESC). E-mail: aab11622@tjsc.jus.br.
} 


\section{INTRODUÇÃO}

No primeiro mês do ano de 2012, um pesquisador do interior de Santa Catarina solicitou ao Museu do Judiciário Catarinense autorização para pesquisar processos judiciais dos séculos XIX e XX. Naquele momento, o pesquisador buscava especialmente informações contidas em um processo judicial: o referente ao julgamento de José Antônio de Oliveira, vulgo "Zeca Vacariano", acusado por ter assaltado o trem pagador da Estrada de Ferro São Paulo - Rio Grande, em 24 de outubro de 1909 - Apelação Crime n. 1521, de 14 de fevereiro de 1919, da comarca de Campos Novos.

Depois de realizar várias tentativas para encontrar o documento solicitado no acervo documental do Arquivo Central do Poder Judiciário do Estado de Santa Catarina, a Seção de Museu buscou, nos primeiros meses do ano de 2016, novas informações referentes ao processo na comarca de Campos Novos. A $2^{a}$ Vara Cível daquela Comarca, na ocasião, informou que havia realizado doação de processos judiciais à Fundação Cultural Camponovense. Dentre os processos doados, identificou-se aquele relativo ao julgamento de José Antônio de Oliveira.

Embora a localização de acervos judiciais para a realização de pesquisas históricas pareça óbvia, nem sempre os processos judiciais que tramitaram no Poder Judiciário do Estado de Santa Catarina encontram-se armazenados nessa instituição. $\mathrm{Na}$ verdade, como se esclareceu durante a pesquisa realizada naquela ocasião, processos judiciais podem ser encontrados sob a guarda de diferentes instituições, em todo o Estado.

O caso descrito acima, infelizmente, não se configurava isolado. Além disso, magistrados e servidores nas comarcas e no Tribunal de Justiça de Santa Catarina, com frequência, enfrentavam situações praticamente incontornáveis em relação à localização de determinados processos judiciais. A maior parte dos documentos de guarda permanente não havia sido descrita, nem mesmo os nomes das partes e o ano em que o processo fora autuado eram dados conhecidos.

Peças importantes desse patrimônio arquivístico custodiado pelo Poder Judiciário catarinense mantinham-se, dessa forma, afastadas do campo das pesquisas. Com o objetivo de alterar completamente aquele cenário, a Diretoria de Documentação e Informações do Tribunal de Justiça de Santa Catarina, a partir de 
2016, promoveu a realização de levantamento dos processos judiciais sob a guarda de instituições culturais e/ou de ensino existentes no Estado. E, quanto aos processos judiciais armazenados em seu Arquivo Central, o Tribunal de Justiça de Santa Catarina organizou e catalogou seu acervo de guarda permanente.

Articulavam-se, desse modo, possibilidades reais de transformar um grande conjunto documental acumulado desde fins do século XVIII em um importante patrimônio arquivístico acessível à administração do Poder Judiciário catarinense e fonte para a produção de conhecimento histórico. Neste sentido, é oportuno descrever os procedimentos realizados naquelas atividades e propor algumas reflexões sobre a importância e a necessidade de preservação desses acervos.

\section{AS DIMENSÕES DE UM GRANDE ACERVO DOCUMENTAL E SUA DISPERSÃO NO TERRITÓRIO CATARINENSE}

Os conjuntos documentais armazenados pelo Tribunal de Justiça de Santa Catarina ocupavam grandes galpões nos municípios de São José e Palhoça, nas proximidades de Florianópolis, capital do Estado. Nesses locais, uma pequena parte dos documentos encontrava-se registrada em planilhas, o que facilitava bastante a sua localização. Em contrapartida, a documentação mais antiga, e numerosa, não havia recebido, ainda, qualquer tratamento.

Quanto aos acervos documentais doados pelo Poder Judiciário catarinense a instituições culturais e/ou de ensino até a década de 1990, e aqueles processos judiciais que ainda estavam nos fóruns, eram raras as informações acerca de suas localizações, seu estado de conservação e quantidade. Sendo assim, foram dois os grandes desafios que se impuseram à Diretoria de Documentação e Informações a naquele momento. Primeiro: caracterizar melhor o patrimônio arquivístico do Poder Judiciário catarinense. Segundo: mapear acervos judiciais dispersos por todo o Estado de Santa Catarina.

Foram responsáveis pela realização dessas atividades a Divisão de Arquivo ${ }^{1}$ e a Divisão de Documentação e Memória do Judiciário².

\footnotetext{
1 Principalmente a Seção de Logística de Acervos Arquivísticos, responsável pela triagem e transporte de todos os documentos, e a Seção de Arquivo Temporário, responsável pela catalogação e acondicionamento adequado dos documentos autuados entre os anos de 1946 e 1988.

${ }^{2}$ Seção de Museu, responsável pelo conjunto de processos judiciais autuados até o ano de 1945.
} 
Para superar os desafios impostos, as atividades foram organizadas em 3 (três) eixos principais, quais sejam:

1 - Identificação de todos os documentos judiciais de primeiro grau existentes no Arquivo Central do Poder Judiciário do Estado de Santa Catarina3;

2 - Adequação e melhoramento das informações contidas em cadastramento de acervo de documentos judiciais realizado anteriormente; e

3 - Levantamento do acervo judicial existente no Estado de Santa Catarina, tanto no Poder Judiciário do Estado quanto em instituições culturais e/ou de ensino.

Para realizar a catalogação dos documentos judiciais de primeiro grau existentes na Divisão de Arquivo, e que compõem o acervo de guarda permanente do Poder Judiciário do Estado de Santa Catarina, foi necessário separá-los em dois grandes conjuntos. Primeiro conjunto: processos judiciais autuados até o ano de 1945. Segundo: processos judiciais autuados entre os anos de 1946 e 1988.

O primeiro conjunto documental, de processos autuados até o ano de 1945, ficou sob a responsabilidade da Divisão de Documentação e Memória do Judiciário Seção de Museu. Os trabalhos relativos ao segundo conjunto documental, processos autuados entre os anos de 1946 e 1988 (sem registro no Sistema de Automação Judicial - SAJ), ficaram sob a responsabilidade da Divisão de Arquivo - Seção de Arquivo Temporário.

Os processos autuados até o ano de 1945 foram todos higienizados, eliminando-se eventuais elementos degradadores, tais como clipes e grampos metálicos, e realizando-se a limpeza preliminar de sujidades superficiais, com trincha. Os documentos higienizados receberam capa (cor branca; $\mathrm{pH}$ alcalino no mínimo 8; sem laminação ou qualquer impressão; formato: $47 \mathrm{~cm} \times 33 \mathrm{~cm}$; tipo offset; granulometria de $180 \mathrm{mg}$; dobrada). A identificação dos documentos foi feita com lápis de escrever na parte da frente da capa que passou a envolvê-los. Compõem a identificação os seguintes dados: ano de autuação do processo; comarca em que o processo foi autuado; tipo de ação; partes no processo e, em alguns casos, observações (nesse campo é possível esclarecer o assunto de que trata o processo e utilizar palavras-chave, úteis para pesquisas futuras, tais como: terra, fuga, moedas, agressão, imigração, escravidão, vadiagem, indústria, estrada, saúde pública,

\footnotetext{
${ }^{3}$ Também foram catalogados documentos judiciais de segundo grau apensados a documentos judiciais de primeiro grau.
} 
militares, religiosidade, etc.). Após identificados, todos os processos foram catalogados em sistema informatizado, conforme as informações presentes na capa. Os documentos identificados e catalogados foram acondicionados em caixas-arquivo de papelão numeradas sequencialmente. Essas caixas-arquivo foram dispostas na posição horizontal (como medida de preservação do suporte dos documentos), em estantes de aço.

Figura 1 - Higienização de processos judiciais.

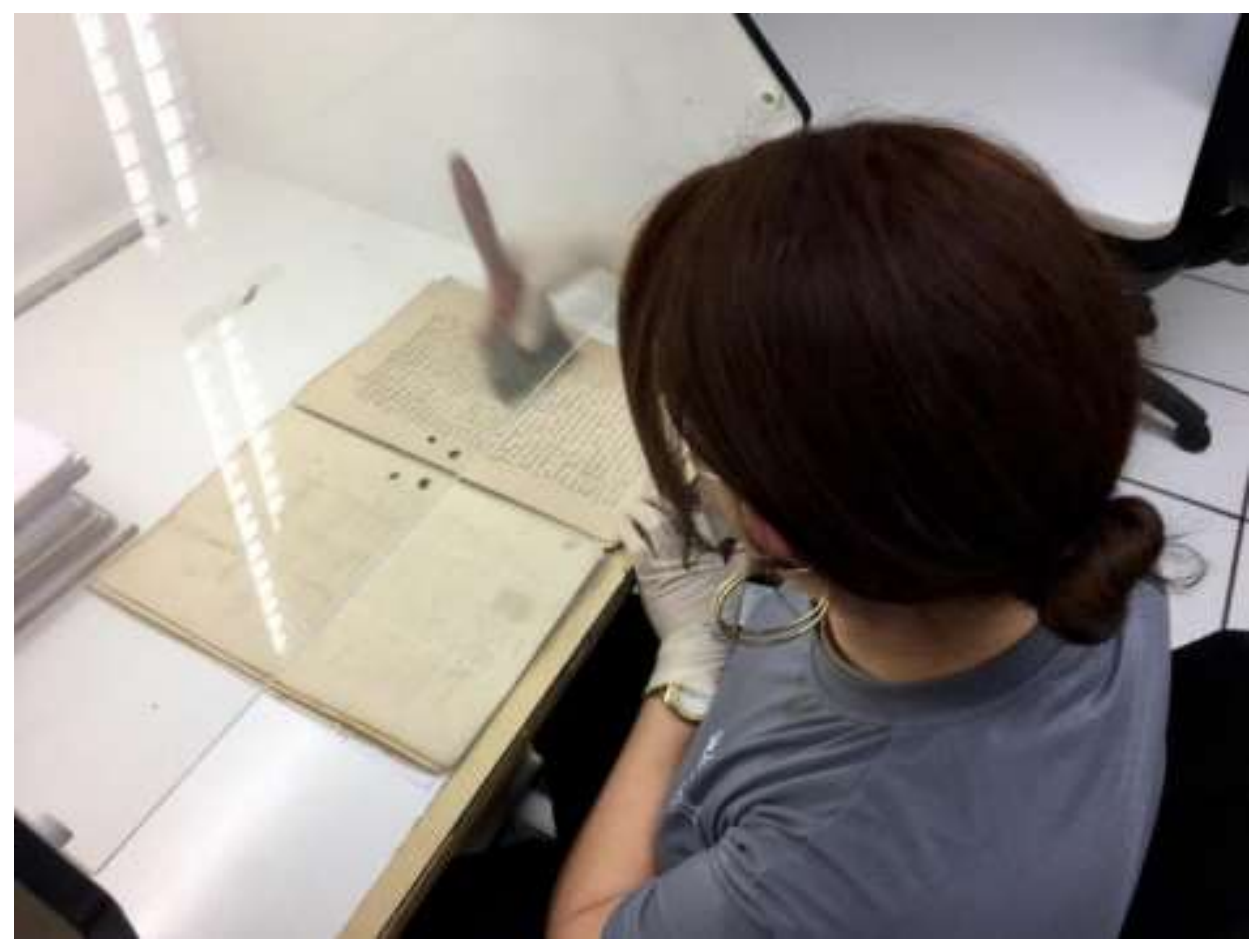

Fonte: Autor (2020). 
Figura 2 - Higienização de processos judiciais.

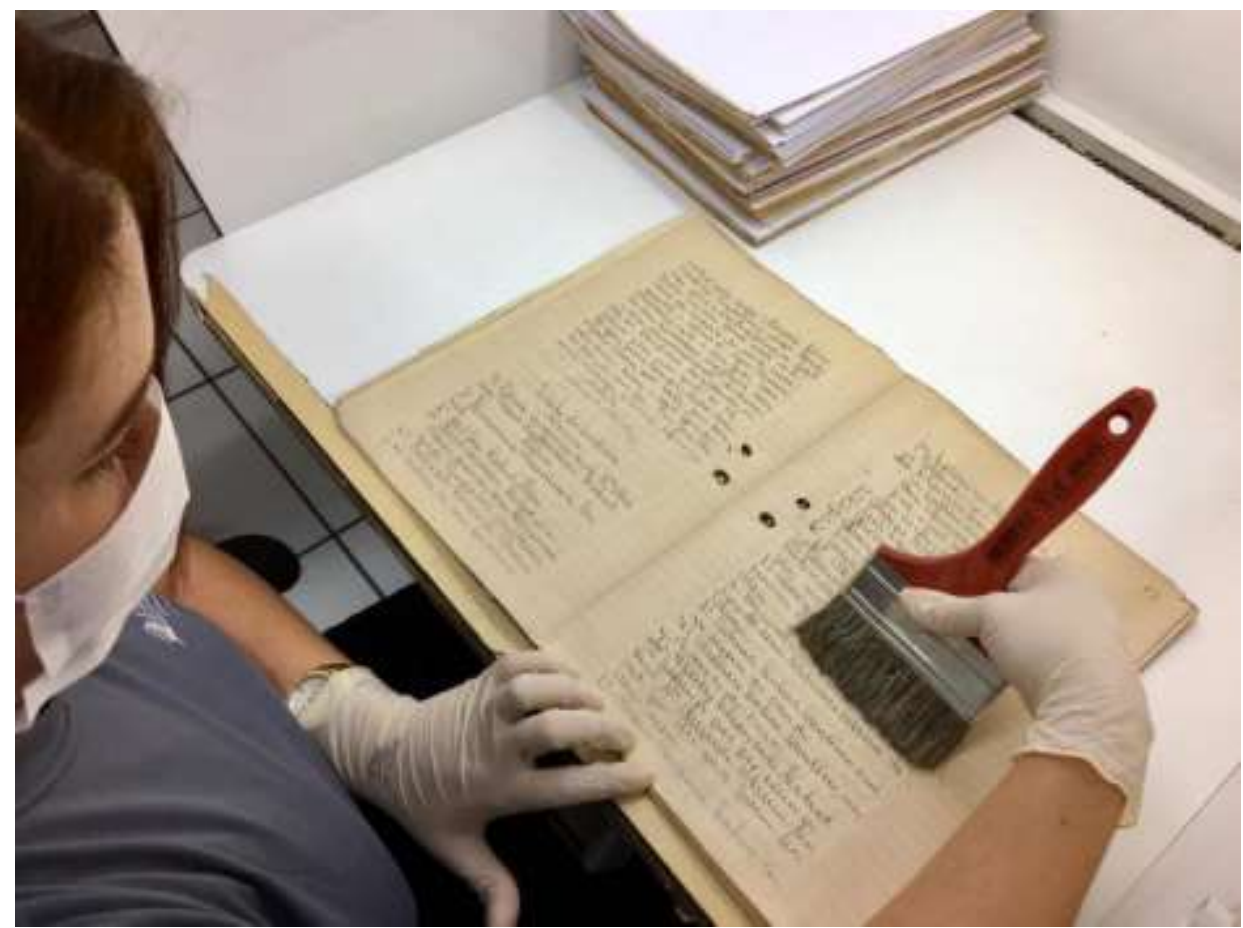

Fonte: Autor (2020).

Figura 3 - Colocação de capa e identificação de processos judiciais.

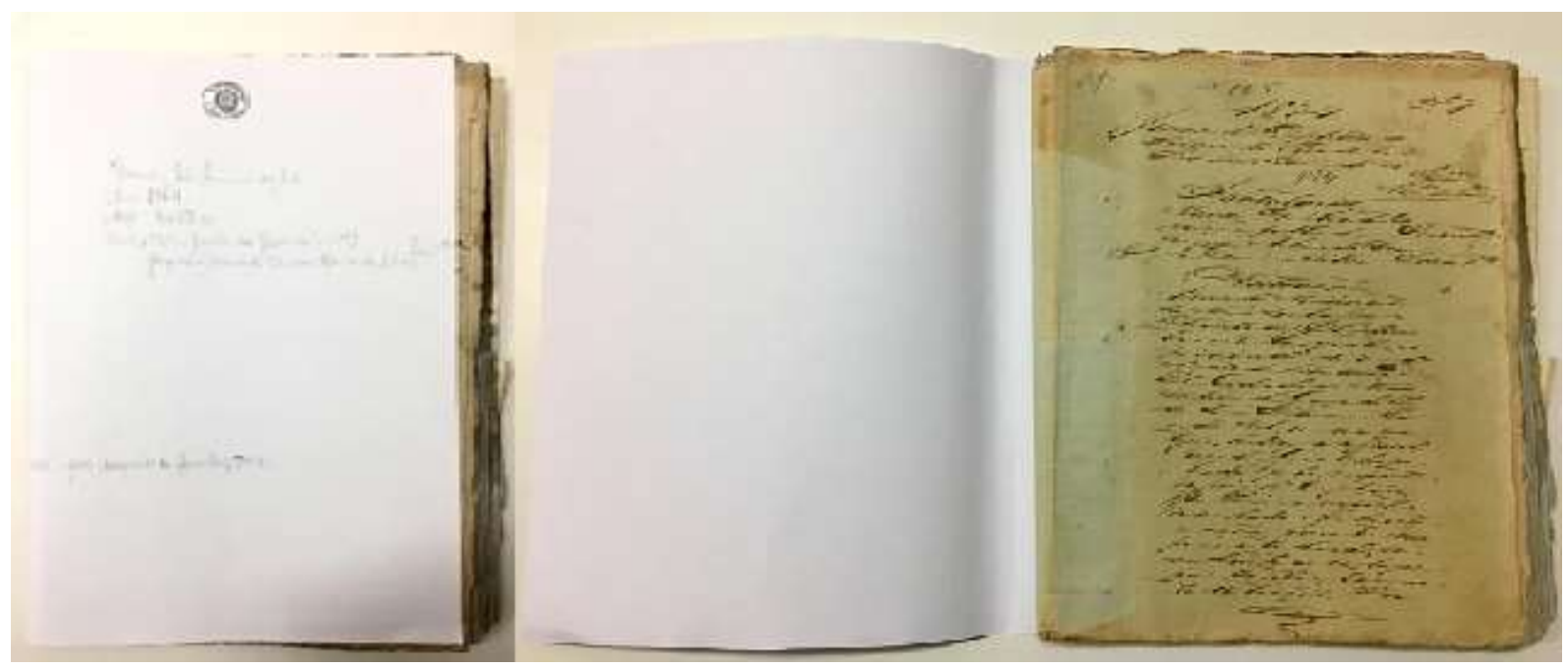

Fonte: Autor (2020). 
Figura 4 - Acondicionamento de processos judiciais.

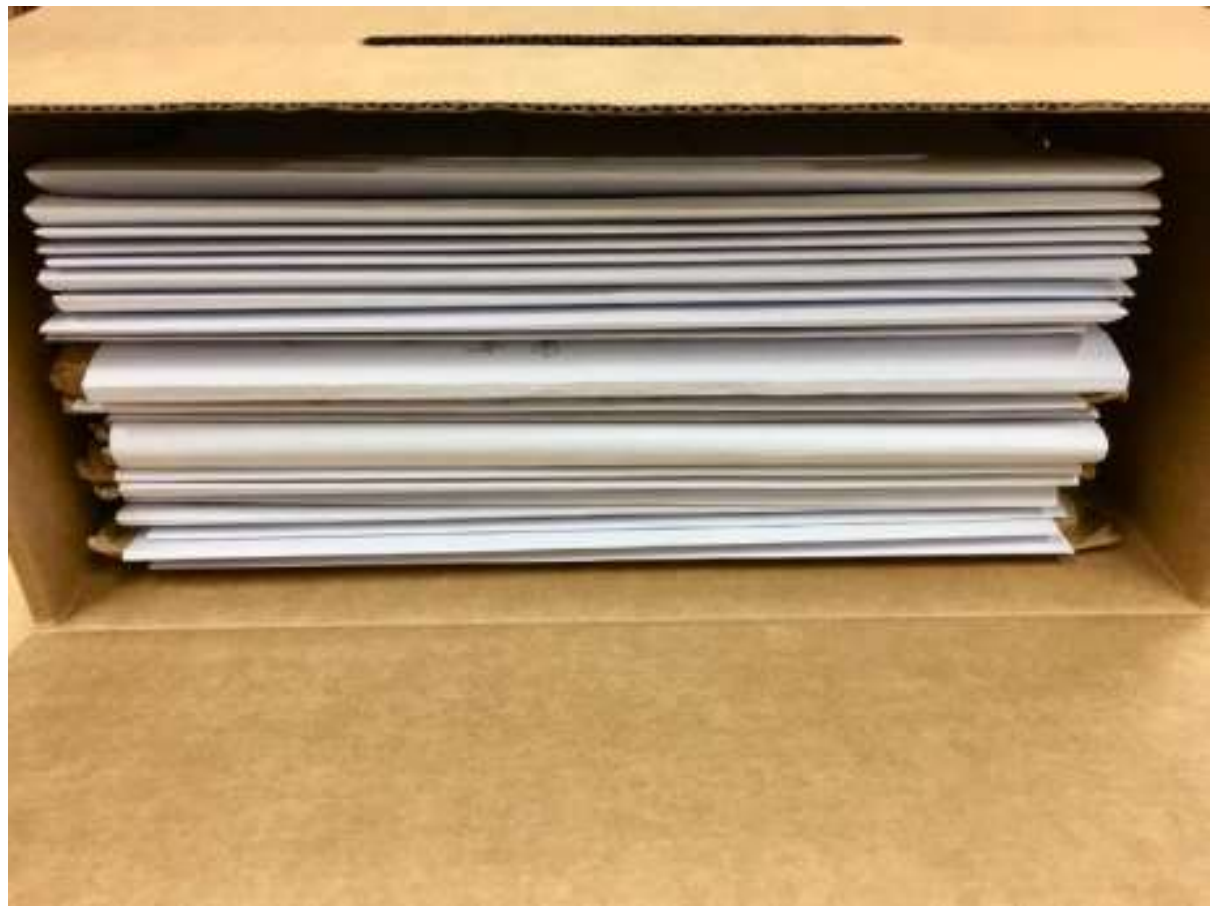

Fonte: Autor (2020).

Figura 5 - Acondicionamento de processos judiciais.

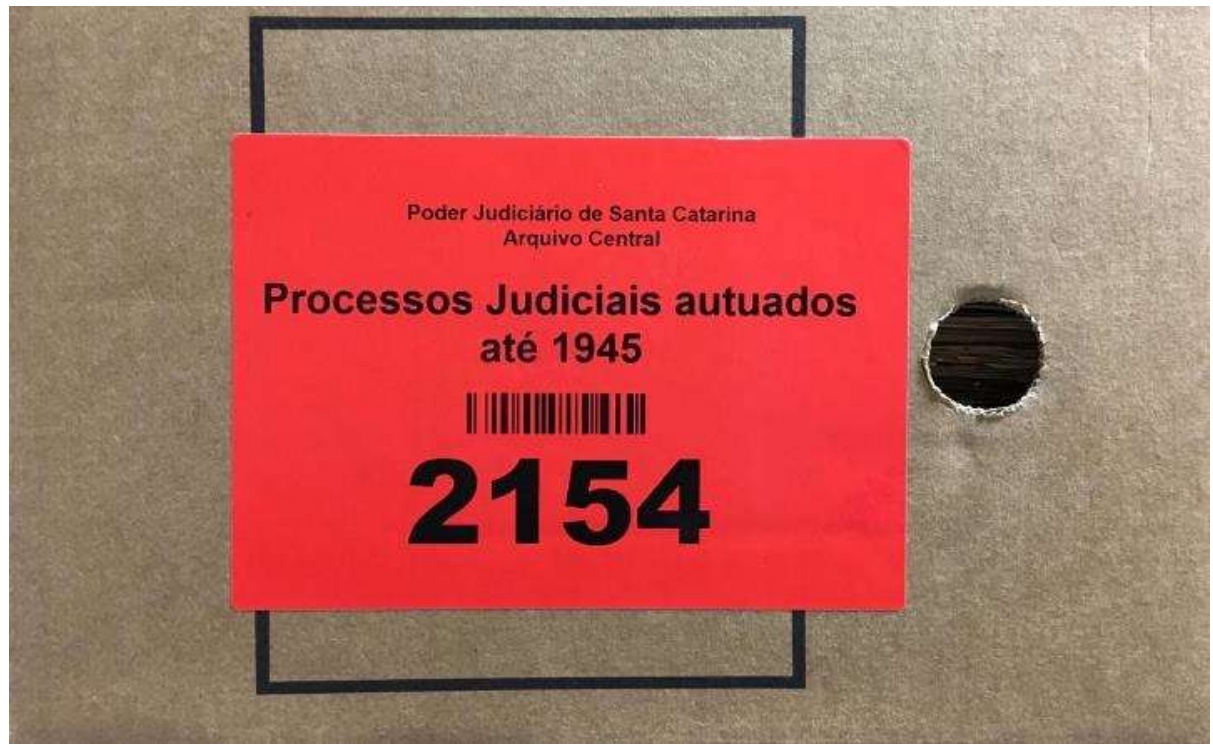

Fonte: Autor (2020).

A Seção de Arquivo Temporário, que lidou com processos mais recentes, e, portanto, mais bem conservados, realizou procedimento simplificado de catalogação do segundo conjunto documental (processos autuados entre os anos de 1946 e 1988). Os servidores dessa Seção utilizaram os dados presentes nas capas dos processos 
(número, ano de autuação, comarca e partes) para realizar a catalogação em sistema informatizado, acrescentando informações quanto ao número de volumes que compõem o processo e nomenclaturas de partes que divergem dos registros cartorários (nomes pelos quais pessoas são vulgarmente conhecidas). Processos judiciais com folhas soltas e/ou sem capa receberam capa (cor branca; $\mathrm{pH}$ alcalino no mínimo 8; sem laminação ou qualquer impressão; formato: $47 \mathrm{~cm} \times 33 \mathrm{~cm}$; tipo offset; granulometria de $180 \mathrm{mg}$; dobrada). Após a catalogação, todos os processos foram acondicionados em caixas-arquivo de papelão numeradas sequencialmente. Essas caixas-arquivo foram dispostas em estantes de aço, na posição vertical.

Antes do ano de 2016, contudo, alguns documentos judiciais já tinham sido catalogados, só que em mais de uma base de dados. Havia uma base de dados com documentos manuscritos da comarca da Capital, outra com documentos manuscritos da comarca de Lages e uma terceira base com documentos, na maior parte manuscritos, provenientes de várias comarcas do Estado. Essa, a maior de todas, estava organizada por comarca e década de autuação, o que tornava possível a existência de várias caixas-arquivo praticamente vazias. Isso porque, em alguns casos, havia somente um ou dois processos judiciais catalogados em uma determinada comarca em uma década específica. O primeiro procedimento adotado para racionalizar essas bases de dados foi a classificação dos documentos pela data de autuação (autuados até o ano de 1945 e autuados entre os anos de 1946 e 1988). Depois disso todos os processos judiciais receberam novas capas e foram catalogados em uma das duas bases de dados (de processos autuados até o ano de 1945 ou de processos autuados entre os anos de 1946 e 1988), descartando-se as anteriores.

O levantamento do acervo judicial existente no Estado de Santa Catarina, tanto no Poder Judiciário quanto em instituições culturais e/ou de ensino, foi realizado pela Seção de Museu da Divisão de Documentação e Memória do Judiciário. Foram enviadas mensagens eletrônicas para todas as secretarias de foro do Estado e para as instituições culturais existentes nas sedes das comarcas catarinenses, notadamente casas de cultura e arquivos públicos municipais e estadual. Também foram consultadas algumas universidades, quando necessário. Esse trabalho envolveu as seguintes etapas: levantamento de números telefônicos e de endereços eletrônicos de todas as instituições; envio de mensagem eletrônica para todas as 
instituições com questionamento acerca da existência, ou não, de acervo documental do Poder Judiciário do Estado; organização e compilação das informações recebidas por mensagem eletrônica.

Das 677 (seiscentas e setenta e sete) mensagens enviadas, 50 (cinquenta) foram respondidas. Dessas, 34 (trinta e quatro) continham respostas negativas quanto à existência de acervo documental do Poder Judiciário do Estado, e 16 (dezesseis) continham respostas afirmativas ${ }^{4}$.

Os procedimentos que envolveram a identificação e a catalogação de processos judiciais existentes no Arquivo Central do Poder Judiciário do Estado de Santa Catarina em sistema informatizado tornaram possível, pela primeira vez, a realização de um breve diagnóstico referente ao patrimônio arquivístico sob a guarda do Tribunal de Justiça ${ }^{5}$. Ou seja, durante as atividades de catalogação foi possível verificar, e melhorar, as condições de armazenamento, aferir o estado de conservação dos documentos, tornar preciso o espaço físico ocupado pelo acervo de guarda permanente, conhecer o volume documental e, por fim, identificar o gênero de documentos que compõem esse acervo (textual, audiovisual, cartográfico, iconográfico etc. $)^{6}$.

Catalogaram-se 104.917 (cento e quatro mil novecentos e dezessete) processos do primeiro conjunto documental (autuados até o ano de 1945). Esses foram inseridos em três diferentes sistemas, e estão distribuídos do seguinte modo:

\footnotetext{
4 Há casos com mais de uma resposta para a mesma comarca. Isso porque tanto a instituição cultural quanto a Secretaria de Cultura municipal responderam aos e-mails enviados pela Seção de Museu.

${ }^{5}$ Ressalta-se que o levantamento realizado não alcança todo o universo de documentos sob a guarda do Arquivo Central do PJSC. O principal objetivo dessa atividade foi o de identificar os processos judiciais que não possuíam nenhum registro e/ou cadastro em sistema informatizado. Desse modo, ficaram de fora desse diagnóstico toda a documentação administrativa e os processos judiciais exclusivamente do Tribunal de Justiça, ou seja, que não tramitaram em nenhuma comarca.

${ }^{6}$ Também é necessário ter em conta que não estão contabilizadas em torno de 150 caixas-arquivo com partes de processos, 54 caixas-arquivo com processos que contêm fungo e 138 caixas-arquivo com processos tão deteriorados que é impossível identificá-los. Quanto ao primeiro grupo de caixas-arquivo, esse ainda será alvo de esforços para remontagem ou, pelo menos, identificação das partes envolvidas (sem data para o início dessa atividade). Quanto aos processos que contêm fungos e os que estão deteriorados, eles serão objeto de contratação de serviço de fumigação e de restauração. Somente após essa etapa é que esses processos poderão ser identificados.
} 
Tabela 1 - Processos judiciais autuados até o ano de 1945 nos diferentes sistemas de catalogação.

Cadastrados no sistema -45

Total

Fonte: Autor (2020).

O gráfico abaixo é uma representação de como esses processos estão distribuídos entre os três sistemas. Percebe-se que a maior parte do acervo autuado até 1945 (83\%) encontra-se cadastrada no sistema -45.

Gráfico 1 - Distribuição de processos judiciais autuados até o ano de 1945 catalogados em diferentes sistemas.

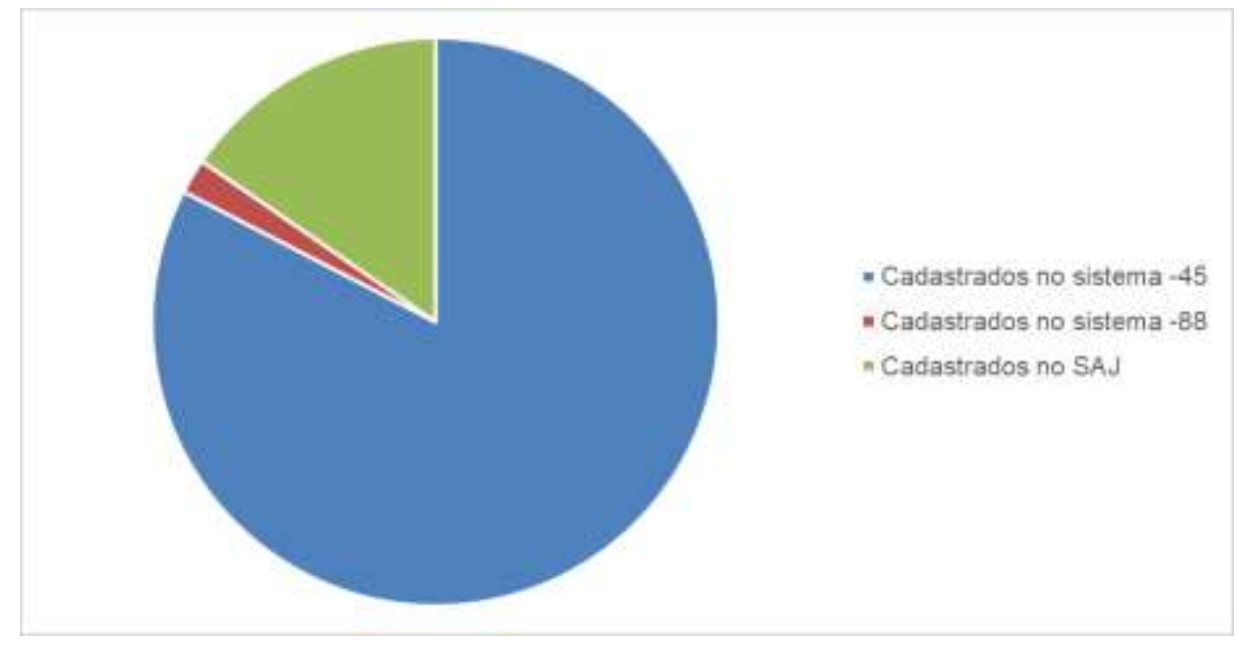

Fonte: Autor (2020).

Os maiores conjuntos documentais desse acervo são representados pelas comarcas da Capital (17\%), São José (15\%), Mafra (8\%), Biguaçu $(7,5 \%)$ e Lages $(7 \%)$. 
Tabela 2 - Processos judiciais autuados até o ano de 1945, por comarca e sistema de catalogação.

\begin{tabular}{|c|c|c|c|c|}
\hline Comarca & Sistema -45 & Sistema -88 & SAJ & Total \\
\hline Abelardo Luz & & & 1 & 1 \\
\hline Araranguá & 4.131 & 393 & 841 & 5.365 \\
\hline Balneário Camboriú & & & 18 & 18 \\
\hline Balneário Piçarras & & & 1 & 1 \\
\hline Biguaçu & 7.807 & 17 & 2 & 7.826 \\
\hline Blumenau & 392 & 2 & 78 & 472 \\
\hline Bom Retiro & 2.952 & & 89 & 3.041 \\
\hline Brusque & 268 & & 628 & 896 \\
\hline Caçador & 669 & 1 & 71 & 741 \\
\hline Campos Novos & 118 & & 327 & 445 \\
\hline Canoinhas & 1.319 & 96 & 308 & 1.723 \\
\hline Capinzal & & & 3 & 3 \\
\hline Capital & 16.547 & 306 & 772 & 17.625 \\
\hline Chapecó & 361 & 1 & 8 & 370 \\
\hline Concórdia & 722 & & 7 & 729 \\
\hline Criciúma & 15 & & 169 & 184 \\
\hline Curitibanos & 801 & & 2 & 803 \\
\hline Forquilhinha & & & 2 & 2 \\
\hline Gaspar & & & 6 & 6 \\
\hline Herval do Oeste & & & 1 & 1 \\
\hline Ibirama & 5 & & 1.541 & 1.546 \\
\hline Indaial & 2.330 & 5 & 972 & 3.307 \\
\hline Itaiópolis & & & 5 & 5 \\
\hline Itajaí & 69 & & 6 & 75 \\
\hline Jaraguá do Sul & 15 & & 988 & 1.003 \\
\hline Joaçaba & 155 & & 2 & 157 \\
\hline Joinville & 1.474 & & 78 & 1.552 \\
\hline Lages & 6.804 & 547 & 257 & 7.608 \\
\hline Laguna & 2.894 & & 1.993 & 4.887 \\
\hline Lauro Müller & & 1 & 2 & 3 \\
\hline Mafra & 5.521 & 147 & 2.308 & 7.976 \\
\hline Maravilha & & & 2 & 2 \\
\hline Orleans & 1.453 & 59 & 71 & 1.583 \\
\hline Palhoça & 2.762 & & 3 & 2.765 \\
\hline Palmitos & & & 4 & 4 \\
\hline Papanduva & & & 3 & 3 \\
\hline Pomerode & & & 1 & 1 \\
\hline Ponte Serrada & & & 1 & 1 \\
\hline Porto União & 51 & & 157 & 208 \\
\hline Rio do Sul & 1.269 & & 223 & 1.492 \\
\hline Rio Negrinho & & & 2 & 2 \\
\hline Sto Amaro da Imperatriz & & & 1 & 1 \\
\hline São Bento do Sul & 2.744 & & 42 & 2.786 \\
\hline São Francisco do Sul & 2.456 & & 3 & 2.459 \\
\hline São Joaquim & 1.546 & 3 & 2.177 & 3.726 \\
\hline São José & 15.274 & 43 & 57 & 15.374 \\
\hline São Lourenço do Oeste & & & 18 & 18 \\
\hline Sombrio & & & 3 & 3 \\
\hline Tijucas & 2.933 & 82 & 1.854 & 4.869 \\
\hline Timbó & & & 26 & 26 \\
\hline Tubarão & 209 & 2 & 1 & 212 \\
\hline Turvo & & & 2 & 2 \\
\hline Urussanga & 541 & 380 & 17 & 938 \\
\hline Videira & & & 4 & 4 \\
\hline Xanxerê & & & 6 & 6 \\
\hline Xaxim & & & 2 & 2 \\
\hline
\end{tabular}

Fonte: Autor (2020). 
O segundo conjunto documental - processos autuados entre os anos de 1946 e 1988 -, muito maior que o primeiro, é composto por 1.154 .006 (um milhão cento e cinquenta e quatro mil e seis) processos judiciais, e encontra-se cadastrado em dois sistemas:

Tabela 3 - Processos judiciais autuados entre 1946 e 1988 em diferentes sistemas de catalogação.

\begin{tabular}{lc} 
Cadastrados no sistema -88 & 466.340 \\
Cadastrados no SAJ & 687.666 \\
\hline Total & $\mathbf{1 . 1 5 4 . 0 0 6}$
\end{tabular}

Fonte: Autor (2020).

Gráfico 2 - Distribuição de processos judiciais autuados entre 1946 e 1988 em diferentes sistemas.

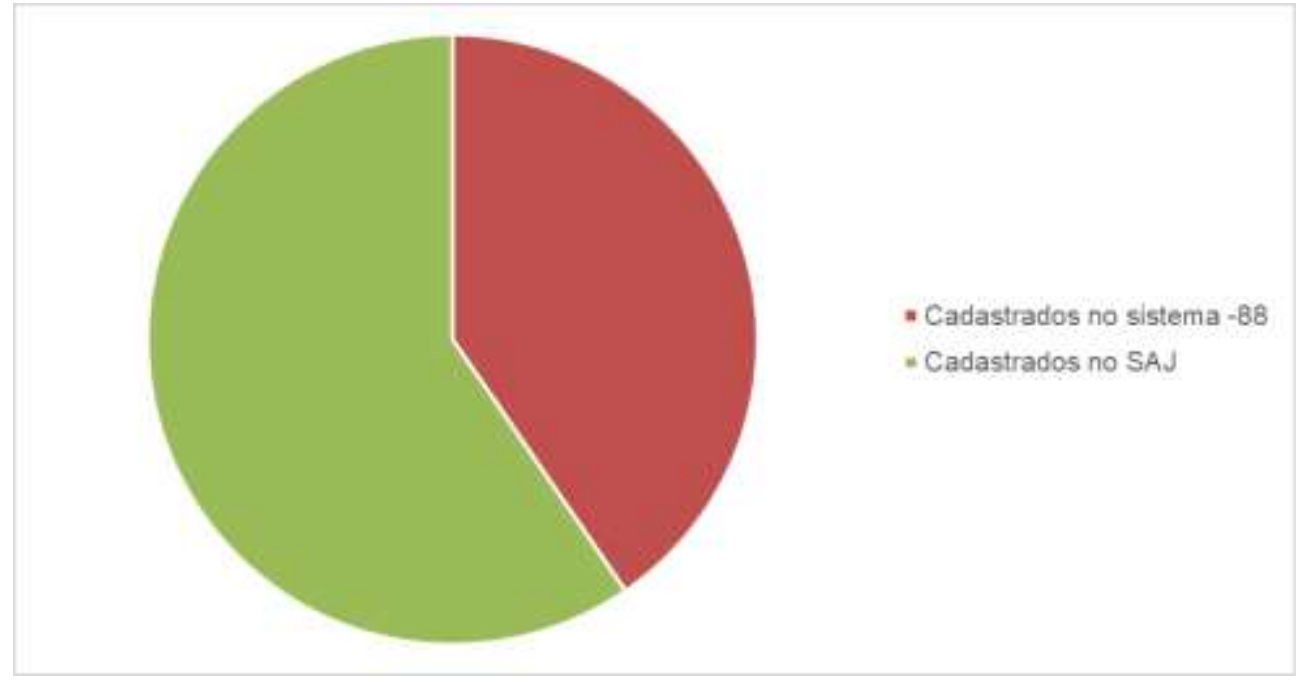

Fonte: Autor (2020).

O gráfico acima demonstra que existe certo equilíbrio na quantidade de processos judiciais cadastrados em cada um dos sistemas $(60 \%$ foram cadastrados no SAJ e $40 \%$ no sistema -88).

Em relação à comarca de origem, porém, existem diferenças importantes. $\mathrm{O}$ maior quantitativo é da comarca da Capital, que representa $19 \%$ de todo o acervo. $O$ segundo maior conjunto, da comarca de Joinville, equivale a somente 5\%. Em terceiro lugar aparecem Lages e Blumenau, com pouco mais de 4\% cada uma. Já as comarcas de Criciúma e São José geraram, cada uma, em torno de 3\% do acervo. 
Tabela 4 - Processos judiciais autuados entre 1946 e 1988, por comarca e sistema de catalogação.

\begin{tabular}{|c|c|c|c|}
\hline Comarca & Sistema -88 & SAJ & Total \\
\hline Abelardo Luz & 4 & 2.594 & 2.598 \\
\hline Anchieta & 253 & 263 & 516 \\
\hline Anita Garibaldi & 19 & 4.124 & 4.143 \\
\hline Ascurra & 131 & 40 & 171 \\
\hline Araquari & 2 & 47 & 49 \\
\hline Araranguá & 11.758 & 16.687 & 28.445 \\
\hline Armazém & 5 & 8 & 13 \\
\hline Balneário Camboriu & 19.110 & 5.121 & 24.231 \\
\hline Balneário Piçarras & 20 & 3.497 & 3.517 \\
\hline Barra Velha & 17 & 1.356 & 1.373 \\
\hline Biguaçu & 8.321 & 1.660 & 9.981 \\
\hline Blumenau & 34.557 & 14.661 & 49.218 \\
\hline Bom Retiro & 3.851 & 3.897 & 7.748 \\
\hline Braço do Norte & 15 & 8.548 & 8.563 \\
\hline Brusque & 1.206 & 16.391 & 17.597 \\
\hline Caçador & 3.207 & 7.053 & 10.260 \\
\hline Camboriu & 1.818 & 44 & 1.862 \\
\hline Campo Belo do Sul & 1 & 19 & 20 \\
\hline Campo Erê & 6 & 4.771 & 4.777 \\
\hline Campos Novos & 237 & 13.123 & 13.360 \\
\hline Canoinhas & 10.396 & 1.726 & 12.122 \\
\hline Capinzal & 7.853 & 1.636 & 9.489 \\
\hline Capital & 105.554 & 112.700 & 218.254 \\
\hline Capivari de Baixo & & 13 & 13 \\
\hline Catanduvas & 2 & 6 & 8 \\
\hline Chapecó & 9.877 & 10.112 & 19.989 \\
\hline Concórdia & 12.540 & 1.955 & 14.495 \\
\hline Coronel Freitas & & 8 & 8 \\
\hline Correia Pinto & 5 & 25 & 30 \\
\hline Criciúma & 220 & 40.588 & 40.808 \\
\hline Cunha Porã & 35 & 609 & 644 \\
\hline Curitibanos & 249 & 13.843 & 14.092 \\
\hline Descanso & & 52 & 52 \\
\hline Dionísio Cerqueira & 13 & 805 & 818 \\
\hline Forquilhinha & 1 & 1 & 2 \\
\hline Fraiburgo & 45 & 2.709 & 2.754 \\
\hline Garopaba & 8 & 97 & 105 \\
\hline Garuva & 31 & 4 & 35 \\
\hline Gaspar & 4.572 & 4.319 & 8.891 \\
\hline Guaramirim & 16 & 3.870 & 3.886 \\
\hline Herval do Oeste & 16 & 4 & 20 \\
\hline Ibirama & 34 & 14.190 & 14.224 \\
\hline Içara & 46 & 2.183 & 2.229 \\
\hline Imaruí & 3.158 & 373 & 3.531 \\
\hline Imbituba & 10 & 5.655 & 5.665 \\
\hline Indaial & 13.294 & 4.478 & 17.772 \\
\hline Ipumirim & 13 & 1 & 14 \\
\hline Itá & 1 & & 1 \\
\hline Itaiópolis & 56 & 12.099 & 12.155 \\
\hline Itajaí & 3.563 & 3.010 & 6.573 \\
\hline Itapema & 27 & 86 & 113 \\
\hline Itapiranga & 4 & 4.070 & 4.074 \\
\hline Itapoá & & 7 & 7 \\
\hline Ituporanga & 3.735 & 7.550 & 11.285 \\
\hline Jaguaruna & 2 & 7 & 9 \\
\hline Jaraguá do Sul & 146 & 16.958 & 17.104 \\
\hline Joaçaba & 6.260 & 648 & 6.908 \\
\hline Joinville & 33.919 & 27.414 & 61.333 \\
\hline Lages & 35.430 & 19.478 & 54.908 \\
\hline Laguna & 1.515 & 16.962 & 18.477 \\
\hline
\end{tabular}




\begin{tabular}{|c|c|c|c|}
\hline Comarca & Sistema -88 & SAJ & Total \\
\hline Lauro Müller & 131 & 316 & 447 \\
\hline Lebon Régis & & 1.608 & 1.608 \\
\hline Mafra & 4.362 & 15.370 & 19.732 \\
\hline Maravilha & 1.608 & 9.468 & 11.076 \\
\hline Meleiro & & 32 & 32 \\
\hline Modelo & 302 & 3 & 305 \\
\hline Mondaí & 14 & 3.014 & 3.028 \\
\hline Navegantes & 14 & 17 & 31 \\
\hline Orleans & 2.917 & 8.546 & 11.463 \\
\hline Otacílio Costa & & 11 & 11 \\
\hline Palhoça & 9.858 & 6.016 & 15.874 \\
\hline Palmitos & 6.458 & 4.439 & 10.897 \\
\hline Papanduva & 4 & 299 & 303 \\
\hline Pinhalzinho & 8 & 6.515 & 6.523 \\
\hline Pomerode & 2.435 & 1.775 & 4.210 \\
\hline Ponte Serrada & 1.703 & 129 & 1.832 \\
\hline Porto Belo & & 10 & 10 \\
\hline Porto União & 83 & 5.842 & 5.925 \\
\hline Presidente Getúlio & & 45 & 45 \\
\hline Quilombo & 2 & 853 & 855 \\
\hline Rio do Campo & & 5 & 5 \\
\hline Rio do Oeste & & 50 & 50 \\
\hline Rio do Sul & 817 & 21.444 & 22.261 \\
\hline Rio Negrinho & 88 & 4.561 & 4.649 \\
\hline Santa Cecília & 38 & 1.809 & 1.847 \\
\hline Santa Rosa do Sul & & 17 & 17 \\
\hline Sto Amaro da Imperatriz & 2.481 & 272 & 2.753 \\
\hline São Bento do Sul & 14.825 & 1.556 & 16.381 \\
\hline São Carlos & 49 & 1.667 & 1.716 \\
\hline São Domingos & 2 & 2.634 & 2.636 \\
\hline São Francisco do Sul & 120 & 8.770 & 8.890 \\
\hline São João Batista & 2.867 & 129 & 2.996 \\
\hline São Joaquim & 4.946 & 9.115 & 14.061 \\
\hline São José & 18.756 & 18.202 & 36.958 \\
\hline São José do Cedro & 2 & 2.614 & 2.616 \\
\hline São Lourenço do Oeste & 14 & 8.646 & 8.660 \\
\hline São Miguel do Oeste & 427 & 23.344 & 23.771 \\
\hline Seara & 7 & 2.730 & 2.737 \\
\hline Sombrio & 1.984 & 5.763 & 7.747 \\
\hline Taió & 17 & 8.010 & 8.027 \\
\hline Tangará & 8 & 3.367 & 3.375 \\
\hline Tijucas & 972 & 8.941 & 9.913 \\
\hline Timbó & 48 & 8.757 & 8.805 \\
\hline Trombudo Central & 9 & 5.261 & 5.270 \\
\hline Tubarão & 8.066 & 19.058 & 27.124 \\
\hline Turvo & 8.117 & 1.129 & 9.246 \\
\hline Urubici & 19 & 3.898 & 3.917 \\
\hline Urussanga & 16.712 & 1.632 & 18.344 \\
\hline Videira & 9.555 & 3.126 & 12.681 \\
\hline Xanxerê & 8.153 & 6.052 & 14.205 \\
\hline Xaxim & 62 & 6.644 & 6.706 \\
\hline
\end{tabular}

Fonte: Autor (2020).

Esse é, até agora, o acervo de guarda permanente do Poder Judiciário catarinense sob custódia da Divisão de Arquivo do Tribunal de Justiça. Entretanto, como assinalado anteriormente, ainda existem muitos documentos judiciais dispersos pelo Estado, e que necessitam ser descritos e catalogados. Esses documentos encontram-se em diversos fóruns e em diferentes instituições culturais e/ou de ensino. 
Nas comarcas, acredita-se que haja mais de 100.000 (cem mil) processos judiciais autuados até o ano de 1945. Contudo, o levantamento realizado permitiu contabilizar um pouco menos:

Tabela 5 - Processos judiciais autuados até o ano de 1945 sob custódia das comarcas.

\begin{tabular}{ll} 
Comarca & Processos judiciais \\
\hline lbirama & 1.536 \\
Curitibanos & $5.000^{\star}$ \\
Porto União & $19.600^{\star *}$ \\
Laguna & 1 \\
Lages & $63.910^{\star}$ \\
São Joaquim & $630^{*}$ \\
Palhoça & $1.700^{*}$ \\
Araranguá & $2.560^{*}$ \\
\hline Total & 94.937 \\
* valor aproximado & \\
** valor aproximado de processos judiciais não cadastrados no SAJ &
\end{tabular}

Fonte: Autor (2020).

Esses números, não somente de processos como também de comarcas, considerando que o Poder Judiciário do Estado de Santa Catarina conta com 111 comarcas, sugerem, por um lado, a impossibilidade de os servidores nas comarcas contabilizarem seus acervos arquivados e, por outro, a precariedade das condições de armazenamento dos documentos.

Os processos autuados entre os anos de 1946 e 1988 existentes nas comarcas ${ }^{7}$ compõem um conjunto menor se comparado ao anterior:

Tabela 6 - Processos judiciais autuados entre 1946 e 1988 sob custódia das comarcas.

\begin{tabular}{ll} 
Comarca & Processos judiciais* $^{*}$ \\
\hline Abelardo Luz & 105 \\
Lages & 74.832 \\
Palmitos & 50 \\
Palhoça & 10.412 \\
São Francisco do Sul & 2.500 \\
São Joaquim & 100 \\
\hline Total & $\mathbf{8 7 . 9 9 9}$ \\
*alores aproximados &
\end{tabular}

Fonte: Autor (2020).

\footnotetext{
${ }^{7}$ As seguintes comarcas afirmaram não possuir acervo de processos judiciais autuados entre os anos de 1946 e 1988: Herval d'Oeste, Ipumirim, Rio do Campo, Armazém, Capinzal, Braço do Norte, Taió, Itapema, Campos Novos, Içara, Ituporanga, Seara, São Miguel do Oeste, Santo Amaro da Imperatriz, Tubarão, Barra Velha e São Bento do Sul.
} 
Afastados dos edifícios pertencentes ao Poder Judiciário catarinense, os processos judiciais preservados em instituições culturais do Estado, com base nas respostas obtidas, formam o seguinte conjunto:

Tabela 7 - Processos judiciais sob custódia de instituições culturais.

\section{Instituição}

Arquivo Histórico José Ferreira da Silva - Blumenau

Arquivo Público do Município de Itajaí

Arquivo Histórico de Jaraguá do Sul ${ }^{9}$

Fundação Cultural de Brusque

Campos Novos

Joaçaba - Unoesc

Arquivo Histórico de Joinville

Arquivo Casa Candemil - Laguna

Arquivo Público Histórico de Rio do Sul

Arquivo Histórico Municipal de São Bento do Sul

Tubarão

Timbó

Arquivo Público do Estado de SC

Total

* valor aproximado
Processos judiciais *

Não quantificado 8

8.224

7.000

Não quantificado

3.565

10.600

Não quantificado ${ }^{10}$

Não quantificado

Não quantificado

Não quantificado ${ }^{11}$

1.638

7.400

$861^{12}$

39.288

Fonte: Autor (2020).

Esses números revelam, infelizmente, que a maior parte dos acervos doados pelo Poder Judiciário catarinense a instituições culturais e/ou de ensino não foram, ainda, alvo de atividades de organização, higienização, descrição e catalogação. Desse modo, esses conjuntos documentais, que somados podem ultrapassar 100.000 (cem mil) processos judiciais, permanecem desconhecidos e inacessíveis aos pesquisadores.

\section{MATÉRIA PRIMA PARA MUITAS HISTÓRIAS E A PRESERVAÇÃO DOS DOCUMENTOS JUDICIAIS}

Para uma instituição pública, a organização, a descrição e a catalogação de seus documentos de arquivo promovem muitos benefícios, internos e externos. Dentre aqueles, destacam-se a economia dos espaços físicos destinados ao arquivamento, a melhoria na produtividade (agilidade no acesso aos documentos) e o fortalecimento

\footnotetext{
8961 (novecentas e sessenta e uma) caixas-arquivo.

9 Processos autuados, na maior parte, na década de 1980 e nos primeiros anos da década de 1990 . Há também processos criminais autuados em décadas anteriores.

10922 (novecentas e vinte e duas) caixas-arquivo.

113 (três) caixas-arquivo.

12 Desses, 714 processos são recursos que tramitaram no Tribunal da Relação de Porto Alegre e que, em 18 de dezembro de 1972, o Arquivo Público do Rio Grande do Sul transferiu ao Arquivo Público de Santa Catarina.
} 
na segurança das informações institucionais. Além dessas vantagens, criam-se meios que tornam possível o desenvolvimento do conhecimento histórico, facilitando, efetivamente, o acesso de seus conteúdos aos historiadores, sociólogos e antropólogos que se dedicam às pesquisas e ao ensino.

Neste sentido, considerando-se os diferentes períodos históricos que perfazem a história do país, o acervo documental sob custódia do Poder Judiciário de Santa Catarina, ao término das atividades citadas na primeira parte do artigo, distribuise do seguinte modo:

Tabela 8 - Processos judiciais autuados em diferentes períodos históricos.

Período histórico

Período colonial brasileiro ${ }^{13}$

Período imperial brasileiro

Período republicano
Número de processos

Fonte: Autor (2020).

Tabela 9 - Processos judiciais autuados no período imperial brasileiro.

Período imperial brasileiro

Número de processos

Primeiro Reinado ${ }^{15}$

Segundo Reinado ${ }^{16}$

Fonte: Autor (2020).

Tabela 10 - Processos judiciais autuados no período republicano brasileiro.

Período republicano

República Velha ${ }^{17}$

Era Vargas ${ }^{18}$

Período democrático ${ }^{19}$

Ditadura militar 20

Reabertura democrática e promulgação da Constituição de $1988^{21}$
Número de processos

46.717

67.306

145.325

627.641

255.462

Fonte: Autor (2020).

\footnotetext{
${ }^{13}$ Processos autuados até o ano de 1822. Como se sabe, a proclamação da independência aconteceu em 7 de setembro de 1822. Porém, neste trabalho serão considerados, para fins estatísticos, todos os processos autuados até o dia 31 de dezembro de 1822 como pertencentes ao período colonial.

${ }^{14} \mathrm{Em}$ vários processos catalogados no sistema -88 não foi possível identificar o ano de autuação.

${ }^{15}$ Processos autuados entre os anos de 1823 e 1831. Embora esse período histórico se inicie em 7 de setembro de 1822, para fins estatísticos optou-se por considerar o dia 1ํ de janeiro de 1823.

16 Processos autuados entre os anos de 1832 e 1889. Como nos casos anteriores, considera-se sempre os períodos entre $1^{\circ}$ de janeiro e 31 de dezembro de cada ano.

17 Processos autuados entre os anos de 1890 e 1930.

18 1931-1945.

19 1946-1963.

20 1964-1985.

21 1986-1988.
} 
No período colonial, de acordo com a tabela abaixo, os processos judiciais provêm majoritariamente das comarcas da Capital, Lages e São José. Ainda que durante esse período o território catarinense tenha se mantido sob diferentes jurisdições - Ouvidoria de Santa Catarina (1749-1812); comarca de São Pedro do Rio Grande e Santa Catarina (1812-1821) e comarca da Itha de Santa Catarina (a partir de 1821) -, a classificação dos processos judiciais apresenta diferenças em relação a essa estrutura porque foram considerados os vínculos orgânicos com a comarca que manteve esses documentos em seus acervos durante os séculos XIX e XX.

Tabela 11 - Processos judiciais autuados no período colonial brasileiro, por comarca.

\begin{tabular}{ll} 
Comarca & Número de processos \\
\hline Biguaçu & 6 \\
Capital & 65 \\
Lages & 43 \\
São Francisco do Sul & 1 \\
São José & 25 \\
Tijucas & 5 \\
Total & 145
\end{tabular}

Fonte: Autor (2020).

Durante o período imperial brasileiro, a Justiça catarinense passou por mudanças consideráveis. A comarca da llha de Santa Catarina manteve-se até o ano de 1833, quando foi subdividida em duas novas comarcas: a do Norte, com sede em São Miguel, que compreendia também Porto Belo, São Francisco e Lages, e a do Sul, com sede em Desterro, que abrangia São José e Laguna. Em 1849, as duas comarcas foram reorganizadas e mudaram de nome: A Primeira Comarca compreendia a Capital, São Miguel, Porto Belo e São Francisco. A Segunda Comarca abrangia São José, Laguna e Lages. Em 1856 a Assembleia Legislativa de Santa Catarina alterou novamente a divisão judiciária da província, dessa vez aumentando para quatro o número de comarcas. As vilas de Desterro e de São Miguel constituíam a comarca da Capital, a comarca de São José encerrava os termos das vilas de São José e de Lages, a comarca de Santo Antônio dos Anjos ficou circunscrita à vila de Laguna e seus termos, e a comarca de Nossa Senhora da Graça compreendia as vilas de São Francisco e Porto Belo e seus termos. Depois de dois anos as comarcas catarinenses foram alteradas outra vez. Em 24 de março de 1858 criou-se a comarca de Lages. A vila de São Miguel, que até então pertencia à comarca da Capital, passou a integrar a 
comarca de São José. Em seguida a Lei n. 541, de 11 de abril de 1864, anexou São José à Capital e, portanto, extinguiu a comarca de São José. As vilas de São Miguel e de São Sebastião da Foz do Tijucas passaram a pertencer à comarca de São Miguel. Pouco tempo depois, pela Lei n. 615, de 20 de maio de 1869, o termo de São José passou a compor a comarca de São Miguel, a qual foi denominada comarca de São José. Em 1874 foi criada a comarca de Tijucas (extinta em 1875 e restabelecida em 1890). No ano seguinte, em 1875, foram criadas as comarcas de Curitibanos e de Tubarão. Em 1883 criou-se a comarca de Joinville, e em 1886 a comarca de Blumenau.

Assim como no conjunto de documentos do período anterior, nesse os processos judiciais foram organizados considerando-se a comarca que os conservou até o envio para o Arquivo Central do Poder Judiciário do Estado de Santa Catarina, nos primeiros anos do século XXI. Portanto, não haverá, no catálogo de documentos judiciais, por exemplo, processos identificados como pertencentes à Primeira Comarca ou à comarca de Nossa Senhora da Graça, existentes apenas durante do século XIX.

Desse modo, no período imperial brasileiro é possível encontrar processos judiciais de várias comarcas, conforme tabela abaixo:

Tabela 12 - Processos judiciais autuados no período imperial brasileiro, por comarca.

\begin{tabular}{ll} 
Comarca & Número de processos \\
\hline Araranguá & 69 \\
Biguaçu & 1.258 \\
Blumenau & 10 \\
Campos Novos & 20 \\
Canoinhas & 1 \\
Capital & 2.780 \\
Curitibanos & 173 \\
Itajaí & 42 \\
Joinville & 67 \\
Lages & 2.803 \\
Laguna & 364 \\
Palhoça & 18 \\
Porto União & 1 \\
São Bento do Sul & 53 \\
São Francisco do Sul & 621 \\
São Joaquim & 57 \\
São José & 2.627 \\
São Miguel do Oeste & 8 \\
Tijucas & 604 \\
Tubarão & 23 \\
\hline Total & $\mathbf{1 1 . 5 9 9 ^ { 2 2 \star }}$ \\
\end{tabular}

$22 \mathrm{Em} 15$ processos judiciais não foi possível identificar a comarca. 
Quanto aos assuntos identificados nesse conjunto, há processos judiciais que se referem à imigração e colonização no interior do Estado, à família real e suas posses no Norte de Santa Catarina, à escravidão, às disputas por terra e ao curandeirismo, por exemplo.

No período republicano é possível encontrar processos judiciais que nos remetem à história da medicina, especialmente quanto ao exercício ilegal da profissão, à Revolução Federalista, ao bandoleirismo e à Guerra do Contestado. Além disso, os processos judiciais evidenciam disputas oligárquicas, fornecem indícios de campanhas de higienização (despejos e demolições), lançam luz sobre o movimento tenentista, sobre a Revolução de 1923, sobre a história do trabalho (mecanização das atividades, insalubridade no trabalho, trabalho de menores), questões indígenas ("pacificação" dos indígenas, contato entre indígenas e colonos), violência de gênero (defloramentos, estupros e raptos), vida conjugal (separação de corpos e desquite), crimes e relações sociais na urbe, história das religiões (feitiçaria, religiões de matrizes africanas, casas de caridade, irmandades), territorialidade e geopolítica (ocupação dos espaços, posse e registro de terras), história política (alistamento eleitoral, voto), história econômica (transporte, venda de mercadorias, protestos marítimos, falsificação de moedas), genealogia, história da arquitetura, história da educação, modernização (ferrovias, EFSPRG, indústrias), Revolução de 1930, trabalhismo e sindicalização e cassação de mandatos. Esse conjunto documental encontra-se distribuído, por comarcas, do seguinte modo:

Tabela 13 - Processos judiciais autuados no período republicano brasileiro, por comarca.

\begin{tabular}{lllll} 
Comarca & Sistema $\mathbf{- 4 5}$ & Sistema -88 & SAJ & Total \\
\hline Abelardo Luz & & 4 & 2.594 & 2.598 \\
Anchieta & & 253 & 263 & 516 \\
Anita Garibaldi & 19 & 4.124 & 4.143 \\
Ascurra & & 131 & 40 & 171 \\
Araquari & 2 & 47 & 49 \\
Araranguá & & 11.758 & 16.687 & 32.506 \\
Armazém & 4.061 & 5 & 8 & 13 \\
Balneário Camboriu & 1 & 19.110 & 5.121 & 24.232 \\
Balneário Piçarras & & 20 & 3.497 & 3.517 \\
Barra Velha & & 17 & 1.356 & 1.373 \\
Biguaçu & 6.525 & 8.321 & 1.660 & 16.506 \\
Blumenau & 382 & 34.557 & 14.661 & 49.600 \\
Bom Retiro & 2.951 & 3.851 & 3.897 & 10.699 \\
Braço do Norte & & 15 & 8.548 & 8.563 \\
Brusque & 268 & 1.206 & 16.391 & 17.865 \\
Caçador & 669 & 3.207 & 7.053 & 10.929 \\
Camboriu & 1.818 & 44 & 1.862 \\
Campo Belo do Sul & & 1 & 19 & 20
\end{tabular}




\begin{tabular}{|c|c|c|c|c|}
\hline Comarca & Sistema -45 & Sistema -88 & SAJ & Total \\
\hline Campo Erê & & 6 & 4.771 & 4.777 \\
\hline Campos Novos & 98 & 237 & 13.123 & 13.458 \\
\hline Canoinhas & 1.318 & 10.396 & 1.726 & 13.440 \\
\hline Capinzal & 7 & 7.853 & 1.636 & 9.496 \\
\hline Capital & 13.700 & 105.554 & 112.700 & 231.954 \\
\hline Capivari de Baixo & & & 13 & 13 \\
\hline Catanduvas & & 2 & 6 & 8 \\
\hline Chapecó & 361 & 9.877 & 10.112 & 20.350 \\
\hline Concórdia & 722 & 12.540 & 1.955 & 15.217 \\
\hline Coronel Freitas & & & 8 & 8 \\
\hline Correia Pinto & & 5 & 25 & 30 \\
\hline Criciúma & 15 & 220 & 40.588 & 40.823 \\
\hline Cunha Porã & & 35 & 609 & 644 \\
\hline Curitibanos & 628 & 249 & 13.843 & 14.720 \\
\hline Descanso & & & 52 & 52 \\
\hline Dionísio Cerqueira & & 13 & 805 & 818 \\
\hline Forquilhinha & & 1 & 1 & 2 \\
\hline Fraiburgo & & 45 & 2.709 & 2.754 \\
\hline Garopaba & & 8 & 97 & 105 \\
\hline Garuva & & 31 & 4 & 35 \\
\hline Gaspar & & 4.572 & 4.319 & 8.891 \\
\hline Guaramirim & & 16 & 3.870 & 3.886 \\
\hline Herval do Oeste & & 16 & 4 & 20 \\
\hline Ibirama & 5 & 34 & 14.190 & 14.229 \\
\hline Içara & & 46 & 2.183 & 2.229 \\
\hline Imaruí & & 3.158 & 373 & 3.531 \\
\hline Imbituba & 2 & 10 & 5.655 & 5.667 \\
\hline Indaial & 2.330 & 13.294 & 4.478 & 20.102 \\
\hline Ipumirim & & 13 & 1 & 14 \\
\hline 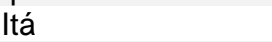 & & 1 & & 1 \\
\hline Itaiópolis & 1 & 56 & 12.099 & 12.156 \\
\hline Itajaí & 27 & 3.563 & 3.010 & 6.600 \\
\hline Itapema & & 27 & 86 & 113 \\
\hline Itapiranga & & 4 & 4.070 & 4.074 \\
\hline Itapoá & & & 7 & 7 \\
\hline Ituporanga & 2 & 3.735 & 7.550 & 11.287 \\
\hline Jaguaruna & & 2 & 7 & 9 \\
\hline Jaraguá do Sul & 15 & 146 & 16.958 & 17.119 \\
\hline Joaçaba & 153 & 6.260 & 648 & 7.061 \\
\hline Joinville & 1.408 & 33.919 & 27.414 & 62.741 \\
\hline Lages & 3.951 & 35.430 & 19.478 & 58.859 \\
\hline Laguna & 2.531 & 1.515 & 16.962 & 21.008 \\
\hline Lauro Müller & & 131 & 316 & 447 \\
\hline Lebon Régis & & & 1.608 & 1.608 \\
\hline Mafra & 5.521 & 4.362 & 15.370 & 25.253 \\
\hline Maravilha & & 1.608 & 9.468 & 11.076 \\
\hline Meleiro & & & 32 & 32 \\
\hline Modelo & & 302 & 3 & 305 \\
\hline Mondaí & & 14 & 3.014 & 3.028 \\
\hline Navegantes & & 14 & 17 & 31 \\
\hline Orleans & 1.452 & 2.917 & 8.546 & 12.915 \\
\hline Otacílio Costa & & & 11 & 11 \\
\hline Palhoça & 2.738 & 9.858 & 6.016 & 18.612 \\
\hline Palmitos & & 6.458 & 4.439 & 10.897 \\
\hline Papanduva & & 4 & 299 & 303 \\
\hline Pinhalzinho & & 8 & 6.515 & 6.523 \\
\hline Pomerode & & 2.435 & 1.775 & 4.210 \\
\hline Ponte Serrada & & 1.703 & 129 & 1.832 \\
\hline Porto Belo & & & 10 & 10 \\
\hline Porto União & 50 & 83 & 5.842 & 5.975 \\
\hline Presidente Getúlio & & & 45 & 45 \\
\hline Quilombo & & 2 & 853 & 855 \\
\hline Rio do Campo & & & 5 & 5 \\
\hline Rio do Oeste & & & 50 & 50 \\
\hline Rio do Sul & 1.269 & 817 & 21.444 & 23.530 \\
\hline Rio Negrinho & 1 & 88 & 4.561 & 4.650 \\
\hline
\end{tabular}




\begin{tabular}{lllll} 
Comarca & Sistema -45 & Sistema -88 & SAJ & Total \\
\hline Santa Cecília & & 38 & 1.809 & 1.847 \\
Santa Rosa do Sul & & & 17 & 17 \\
Sto Amaro da Imperatriz & & 2.481 & 272 & 2.753 \\
São Bento do Sul & 2.690 & 14.825 & 1.556 & 19.071 \\
São Carlos & & 49 & 1.667 & 1.716 \\
São Domingos & & 2 & 2.634 & 2.636 \\
São Francisco do Sul & 1.834 & 120 & 8.770 & 10.724 \\
São João Batista & & 2.867 & 129 & 2.996 \\
São Joaquim & 1.490 & 4.946 & 9.115 & 15.551 \\
São José & 12.589 & 18.756 & 18.202 & 49.547 \\
São José do Cedro & & 2 & 2.614 & 2.616 \\
São Lourenço do Oeste & & 14 & 8.646 & 8.660 \\
São Miguel do Oeste & 3 & 427 & 23.344 & 23.774 \\
Seara & & 7 & 2.730 & 2.737 \\
Sombrio & & 1.984 & 5.763 & 7.747 \\
Taió & & 17 & 8.010 & 8.027 \\
Tangará & & 8 & 3.367 & 3.375 \\
Tijucas & & 972 & 8.941 & 12.238 \\
Timbó & 2.325 & 48 & 8.757 & 8.805 \\
Trombudo Central & & 9 & 5.261 & 5.270 \\
Tubarão & \multirow{2}{*}{186} & 8.066 & 19.058 & 27.310 \\
Turvo & & 8.117 & 1.129 & 9.246 \\
Urubici & 19 & 3.898 & 3.917 \\
Urussanga & 16.712 & 1.632 & 18.885 \\
Videira & 541 & 9.555 & 3.126 & 12.682 \\
Xanxerê & 1 & 8.153 & 6.052 & 14.205 \\
Xaxim & & 62 & 6.644 & 6.706 \\
Sarm & & &
\end{tabular}

Fonte: Autor (2020).

Ao lançar luz sobre todo esse acervo é possível reconstituir importantes momentos históricos, não somente de Santa Catarina como também do Brasil e do mundo. Quando se reconhece a importância de preservar adequadamente esses documentos, torna-se possível pensar o papel do Arquivo Central do Poder Judiciário catarinense na sociedade contemporânea, e sua relação com os processos de produção da memória social. (GONÇALVES, 2006).

A propósito, os arquivos e a Justiça estão entrelaçados desde o surgimento do conceito de arquivo. De acordo com Jacques Derrida (2001, p. 12), o sentido da palavra arquivo vincula-se ao vocábulo grego arkheîon, que significava, de início, uma casa, um endereço, a residência dos magistrados, os arcontes. Na casa desses magistrados, cidadãos que detinham poder político e representavam a lei, eram depositados, então, os documentos oficiais. Sendo assim, os arcontes, ou seja, os magistrados, eram os guardiões dos arquivos e responsáveis pela segurança física dos documentos. Além disso, eram esses mesmos magistrados que detinham o poder de interpretar a documentação depositada em suas casas.

Nos últimos séculos, tanto na Europa quanto no continente americano, a Justiça distanciou-se das preocupações relacionadas à preservação de documentos 
importantes para a história. As bibliotecas e os arquivos públicos tornaram-se, quase que exclusivamente, os guardiões dos documentos produzidos pela administração pública. Conforme Carlos Bacellar (2006, p. 50), os arquivos públicos dos poderes Executivo e Legislativo, especialmente nas esferas nacional e estadual, são melhor organizados quando comparados aos arquivos mantidos pelo Poder Judiciário brasileiro.

Contudo, nas duas últimas décadas, foram realizadas importantes ações de preservação documental no Poder Judiciário. Merecem destaque, nesse sentido, as atividades desenvolvidas pelo Programa Nacional de Gestão Documental e Memória do Poder Judiciário, do Conselho Nacional de Justiça - CNJ. No Tribunal de Justiça de Santa Catarina, a criação de um museu, no ano de $1991^{23}$, tornou-se o ponto de partida para a preservação da memória institucional e da história da sociedade catarinense. Outro passo nessa direção foi a centralização dos acervos documentais de todo o Estado no Arquivo Central do Poder Judiciário, entre os anos de 2002 e 2004. A partir desse momento o Tribunal de Justiça de Santa Catarina passou a armazenar a maior parte de seu acervo documental em um único local, tornando-se possível saber, mesmo que superficialmente, as dimensões de seu acervo judicial24.

O processo judicial, protagonista nesse cenário, requer cuidados especiais quanto ao uso e preservação das partes que o constituem. Alexandre Veiga afirma, a esse respeito, que os processos judiciais

\begin{abstract}
[...] de modo geral, configuram-se como o produto de uma disputa entre litigantes, os quais procuram construir versões de determinado episódio, procurando convencer o mediador dessa disputa - o juiz de direito ou desembargador - a atender suas solicitações, tornando-os vitoriosos no processo.

Com isso, acabam por reunir, em um mesmo conjunto de documentos, uma quantidade significativa de registros documentais, os quais versam, num primeiro momento, sobre os pontos em disputa, mas que se prestam a outras perspectivas, no sentido de propiciarem a compreensão da dinâmica social. Estão integrados num processo a proposição do autor, as ponderações do réu e a decisão do magistrado. Nas argumentações das partes, para se tornarem críveis, há um conjunto de provas dos fatos, formadas por documentos administrativos, interrogatórios de testemunhas e quaisquer outros elementos que possam servir para convencer o juiz de um ou outro argumento. (VEIGA, 2013, p. 194).
\end{abstract}

${ }^{23}$ O Tribunal de Justiça do Estado de Santa Catarina, por meio da Resolução TJ n. 04, de 6 de fevereiro de 1991, instituiu o Museu do Judiciário Catarinense. Este Museu possui inscrição no Cadastro Nacional de Museus, sob o Código 6.40.47.5700, n. SNIIC: ES-8050.

${ }^{24}$ No ano de 2012 foram iniciadas atividades para que os acervos de processos judiciais vindos das comarcas fossem, de fato, organizados. 
Além de descrições sobre os acontecimentos que levaram as pessoas a procurarem a Justiça, argumentos elaborados pelos advogados, fundamentações legais e decisões de magistrados, nos processos judiciais descortinam-se inúmeros tipos documentais. No acervo do TJSC foram encontrados mapas, plantas, croquis, fotografias, documentos de identificação, exames médicos, jornais e outras publicações. No caso dos mapas, destacam-se aqueles inseridos em processos de disputas por terras e que possuem grandes dimensões (alguns com mais de 4 metros de comprimento). Dentre as plantas, se sobressaem aquelas que dizem respeito aos edifícios urbanos que, em conjunto com plantas de ruas e fotografias encontradas em vários processos, tornam possível a reconstituição de partes de cidades catarinenses significativamente transformadas nas últimas décadas. As fotografias, muito abundantes em processos judiciais que tratam de acidentes de trânsito, além de trazerem à luz detalhes sobre as malhas rodoviárias do passado, sobre o tecido urbano de várias cidades do Estado e sobre as paisagens circundantes, formam um importante repertório de modelos de automóveis e de motocicletas que circulavam em estradas e ruas de Santa Catarina. Quanto aos documentos de identificação, chamam a atenção certidões de nascimento, passaportes estrangeiros e carteiras de trabalho. Os exames médicos estão presentes, especialmente, em processos judiciais trabalhistas, e trazem quantidade expressiva de radiografias. As publicações anexadas aos processos se referem a propagandas, notícias e editais de intimação.

A identificação e catalogação de processos judiciais, bem como dos tipos documentais que os compõem, facilitam o acesso a esse importante patrimônio arquivístico do Estado, até então pouco conhecido e de difícil acesso. Desse modo, as atividades realizadas entre os primeiros meses do ano de 2016 e o início do ano de 2019 (levantamento, identificação e catalogação de documentos) revelam o valor social do patrimônio arquivístico do Tribunal de Justiça de Santa Catarina para o estudo de múltiplos aspectos da história social catarinense, além de tornarem possível a disponibilização efetiva de vasta documentação para consulta pública, fortalecendo a importância do acesso ao arquivo.

De acordo com o arquivista italiano Elio Lodolini (1993, p. 245-252), os documentos nascem para fins práticos, sejam eles administrativos ou jurídicos, e refletem, muitas vezes, o caráter interno da instituição que os produziu. Nesse caso, há documentos que devem ser mantidos, ao menos por um determinado período, 
cobertos pelo segredo de ofício ou pela preservação de sua natureza privada. Por outro lado, existem documentos cuja própria finalidade requer ampla publicidade. Eles asseguram a certeza do direito e possuem um caráter intrinsicamente público. Tratase, entre outros, de cadastros, contratos, sentenças e escrituras. A consulta desses documentos, conforme Elio Lodolini, deve ser facilitada e favorecida pela autoridade pública. Segundo o autor, antes da existência da imprensa, algumas sentenças eram impressas e fixadas em praças públicas, e apregoadas por pregoeiros públicos. Hoje em dia elas têm sua publicação paga em jornais diários, a cargo do condenado.

Para Lodolini, a possibilidade de consulta a vastos acervos documentais por parte dos cidadãos foi reforçada no período mais luminoso da Idade Média, nas comunas italianas. Contudo, durante a decadência da Idade Moderna e a formação dos principados, muitos arquivos se tornaram secretos. Os arquivos das comunas foram transformados em arquivos do príncipe, que proibiu sua livre consulta, admitindo o acesso somente a eruditos que escreveriam histórias que enaltecessem, principalmente, as conquistas da dinastia no poder. Na esteira da Revolução Francesa iniciou-se movimento de abertura e acesso livre aos arquivos, o qual culminou com promulgação de lei garantindo a cada cidadão a livre consulta a documentos que garantissem seus direitos (de forma semelhante ao que já ocorria nas comunas italianas).

Durante o século XIX, a possibilidade de acesso aos acervos arquivísticos difundiu-se por vários países europeus, mas quase sempre esse acesso estava circunscrito à garantia de direitos, não se estendendo à pesquisa. A pesquisa histórica permaneceu, por muitas décadas, como fato excepcional, tanto em grandes arquivos quanto nos menores.

Nos arquivos judiciais, a pesquisa histórica é mais recente ainda, não somente pelas dificuldades de acesso que caracterizavam esses locais, mas também porque os historiadores interessaram-se por esses acervos apenas mais recentemente.

A historiadora francesa Arlette Farge, em ensaio sobre a prática da pesquisa em arquivo e seu papel na escrita da história, traz à luz uma importante faceta dos arquivos judiciais:

Desconcertante e colossal, 0 arquivo atrai mesmo assim. Abre-se brutalmente para um mundo desconhecido em que os rejeitados, os miseráveis e os bandidos fazem a sua parte em uma sociedade vigorosa e instável. Sua leitura provoca de imediato um efeito de real que nenhum impresso, por mais original que seja, pode suscitar [...]. Nada a ver com o 
arquivo; vestígio bruto de vidas que não pediam absolutamente para ser contadas dessa maneira, e que foram coagidas a isso porque um dia se confrontaram com as realidades da polícia e da repressão. Fossem vítimas, querelantes, suspeitos ou delinquentes, nenhum deles se imaginava nessa situação de ter de explicar, reclamar, justificar-se diante de uma polícia pouco afável. Suas palavras são consignadas uma vez ocorrido o fato, e ainda que, no momento, elas tenham uma estratégia, não obedecem à mesma operação intelectual que o impresso. Revelam o que jamais teria sido exposto não fosse a ocorrência de um fato social perturbador. De certo modo, revelam um não dito. $\mathrm{Na}$ brevidade de um acidente que provocou a desordem, ela vem explicar, comentar, relatar como 'aquilo' pôde acontecer em suas vidas, entre vizinhança e trabalho, rua e escadas [...]. O arquivo é uma brecha no tecido dos dias, a visão retraída de um fato inesperado. Nele, tudo se focaliza em alguns instantes de vida de personagens comuns, raramente visitados pela história. (FARGE, 2009, p. 12-14).

Percebe-se, assim, o quanto as atividades de identificação e catalogação da documentação existente no Arquivo Central do Poder Judiciário de Santa Catarina foram, são, e certamente continuarão a ser, nos próximos anos, fundamentais para disponibilizar à sociedade importante acervo documental antes indisponível para pesquisa. Os documentos que formam esse riquíssimo acervo contam o cotidiano da sociedade catarinense ao longo dos séculos XIX e XX e, além disso, o dia a dia de magistrados e servidores do Judiciário do Estado. Trata-se, na verdade, do entrecruzamento de experiências e vozes, relatos de momentos e lugares, "fragmentos de vida cujos segredos e astúcias poéticos teciam o pano de um tempo logo perdido, efêmeras invenções dos 'heróis obscuros' do ordinário, 'artes de fazer' que compõem sem palavras uma 'arte de viver'. (CERTEAU; GIARD; MAYOL, 2009, p. 29).

\section{CONCLUSÕES}

Diante disso conclui-se que a identificação e preservação adequadas do conjunto documental sob a guarda do Tribunal de Justiça de Santa Catarina, bem como a localização de acervos judiciais em instituições culturais no Estado perfazem um importante repertório de documentos que dizem respeito à atuação da Justiça em Santa Catarina, desde o século XVIII. Juntos, esses documentos recuperam partes significativas do percurso acidentado dessa instituição que se transformou em um verdadeiro Poder de Estado no ano de 1988, com a nova Constituição Federal.

A análise dos números alcançados, os quais demonstram importante avanço que garantirá a preservação e o acesso ao patrimônio arquivístico do Poder Judiciário 
de Santa Catarina, revela, contudo, que ainda há muito a ser feito. O tratamento adequado do acervo documental produzido, acumulado e custodiado pelo Judiciário do Estado exige a realização de novas atividades, as quais deverão ser concretizadas oportunamente.

O levantamento realizado nos fóruns de comarcas catarinenses e em instituições culturais e/ou de ensino permitiu vislumbrar a localização de alguns conjuntos documentais produzidos pelo Poder Judiciário do Estado de Santa Catarina, e também forneceu dados necessários ao planejamento de ações para o recolhimento e tratamento desses acervos.

Desse modo, será necessário planejar o recebimento de processos judiciais existentes nas comarcas, priorizando aqueles autuados até o ano de 1988 e sem registro no SAJ; realizar a transferência do acervo de processos judiciais autuados antes do ano de 1946, e que foram cadastrados no SAJ pelas comarcas, para a Seção de Museu. Essa transferência é necessária para que se faça a conservação adequada desses processos (retirada de sujidades, grampos metálicos, acondicionamento na horizontal etc.). Além disso, será necessário realizar a movimentação "Processo selecionado para compor acervo de guarda permanente do PJSC" em todos os processos judiciais autuados até 5 de outubro de 1988 e que se encontram cadastrados no SAJ; contratar os serviços de fumigação e de restauração de documentos e verificar a possibilidade de identificação e remontagem de processos. Como medida preventiva, deverá ser realizada, ainda, a transferência de todos os processos autuados até outubro de 1988 para o sistema de catalogação de processos judiciais (que não seja o SAJ), a fim de compor a integralidade do acervo judicial de guarda permanente, conforme Resolução TJ n. 30, de 3 de dezembro de 2014 (TRIBUNAL DE JUSTIÇA DE SANTA CATARINA, 2014). Aliás, o acervo judicial de guarda permanente do PJSC deverá ser subdivido em três grandes fundos arquivísticos: Processos autuados até 1945 (fim do Estado Novo); Processos autuados entre 1946 e outubro de 1988 (Promulgação da Constituição Federal de 1988); e Processos autuados a partir de outubro de 1988 (selecionados pela Seção de Análise e Eliminação de Autos Findos e Documentos). Será necessário, ainda, realizar levantamento minucioso no Arquivo Público do Estado e no Arquivo Público do Município de Florianópolis, no Arquivo Público do Estado do Rio Grande do Sul e no Arquivo Nacional (principalmente para mapear a existência de processos judiciais 
que tramitaram na comarca da llha de Santa Catarina, instalada em meados do século XVIII, e processos judiciais do Estado de Santa Catarina que tramitaram no Tribunal da Relação de Porto Alegre).

Por fim, a preservação adequada desse patrimônio arquivístico, a promoção de pesquisas históricas, a difusão dos resultados até então alcançados nas atividades de organização, descrição e catalogação dos documentos judiciais, seja por meio de exposições temáticas no Museu do Judiciário Catarinense ou por publicação impressa e disponibilização de catálogos no sítio eletrônico do Tribunal de Justiça de Santa Catarina esclarece, e reforça, importante função social do Poder Judiciário na preservação de memórias. Ao estimular a produção de conhecimento histórico, permitindo com que os pesquisadores acessem com mais facilidade seus acervos documentais, o Tribunal de Justiça de Santa Catarina recupera, de acordo com Jacques Derrida (2001, p. 12), seus vínculos com a guarda de documentos, há muito deixados de lado, e se torna, nessas primeiras décadas do século $X X I$, fonte de importantes transformações sociais, sejam elas resultado de sua atividade-fim, sejam elas resultado de sua capacidade de gerir adequadamente parcela importante do patrimônio arquivístico da sociedade brasileira.

\section{REFERÊNCIAS}

BACELLAR, C. Uso e mau uso dos arquivos. In: PINSKY, C. B. (org.). Fontes históricas. São Paulo: Contexto, 2006.

CERTEAU, M.; GIARD, L.; MAYOL, P. A invenção do cotidiano: morar e cozinhar. Tradução: Ephraim Ferreira Alves; Lúcia Endlich Orth. 2. ed. Petrópolis: Vozes, 2009.

DERRIDA, J. Mal de arquivo: uma impressão freudiana. Tradução: Cláudia de Moraes Rego. Rio de Janeiro: Relume Dumará, 2001.

FARGE, A. O sabor do arquivo. São Paulo: EdUSP, 2009.

GONÇALVES, J. Sombrios umbrais a transpor: arquivos e historiografia em Santa Catarina no século XX, 2006. Tese (Doutorado em História Social) - Faculdade de Filosofia, Letras e Ciências Humanas, Universidade de São Paulo, São Paulo, 2006.

HALBWACHS, M. A memória coletiva. Tradução: Laurent Léon Schaffter. São

Paulo: Vértice: Revista dos Tribunais, 1990.

LODOLINI, E. Archivística: princípios y problemas. Madrid: Arco Libros, 1993. 
TRIBUNAL DE JUSTIÇA DE SANTA CATARINA. Resolução TJ n. 30 - $\mathbf{3}$ de dezembro de 2014. Plano de classificação e tabela de temporalidade unificada dos processos judiciais do poder judiciário do estado de Santa Catarina. Santa Catarina: TJSC, 2014. Disponível em:

http://busca.tjsc.jus.br/buscatextual/integra.do?cdSistema $=1 \&$ cdDocumento $=164961$ $\& c d$ Categoria $=1 \& q=\&$ frase $=\&$ excluir $=\& q u a l q u e r=\&$ prox $1=\&$ prox $2=\&$ proxc $=$. . Acesso em: 27 abr. 2020.

VEIGA, A. acervos da justiça do trabalho como fonte de pesquisa. Revista Brasileira de História, São Paulo, v. 33, n. 65, p. 193-208, 2013. Disponível em: https://www.scielo.br/pdf/rbh/v33n65/08.pdf. Acesso em: 23 jul. 2020. 